\title{
Russian Jews and the Church: a Sociological View
}

\section{LYUDMILA VORONTSOVA \& SERGEI FILATOV}

In all the discussion on the situation of Russian Jews today one basic fact has not been mentioned: a fact that means that this situation is qualitatively different from that in pre-revolutionary Russia or in the countries of the West. The fact is that the majority of modern Russian Jews do not consider themselves to be even nominal Jewish believers. More of them are in fact Christians. Throughout the centuries, antisemitism has been either rooted in religion or at least indirectly or genetically connected with it. Therefore, both the problem of antisemitism and the problem of the Russian Jews' national selfconsciousness have to be formulated anew.

How do Russian Jews view their religious affiliation? In order to answer this and other questions we are using the data we gathered for the Analytical Centre at the Russian Academy of Sciences in 1992 as part of the international sociological research project 'The World view of the Russian Population: Religion, Politics, Morals and Culture'.' Only 8 per cent of Jews were practising, 18 per cent were 'just Christians' ( 52 per cent of Russians), 5 per cent were Orthodox (19 per cent of Russians), 18 per cent were Catholics ( 1 per cent of Russians), 1 per cent were Protestant ( 1 per cent of Russians), 1 per cent were Buddhists and followers of other eastern religions ( 1 per cent of Russians), 23 per cent were atheists ( 7 per cent of Russians) and 53 per cent had difficulty defining their confessional affiliation ( 21 per cent of Russians). Of Jews, 25 per cent consider themselves Christians, then, and only 8 per cent practise Judaism. There are two peculiar features in the perceived confessional affiliation of Jews. Firstly, many Jews are atheists. This evidently results from the fact that in their eyes unbelief and secularisation are linked with the overcoming of interreligious conflict and the 'progressive development of humanity'. Secondly, a particularly large proportion of Jews cannot find themselves a place on the 'confessional map'. These are people who have torn themselves away from their ethnic religious traditions and find it difficult to associate themselves with any other. In this situation, the predominant tendency among Russians is to consider themselves 'just Christian' (this means essentially Orthodox but with an eroded, non-dogmatic, eclectic worldview) - a comfortable way of being part of the international Russian religious culture which at present predominates in our social consciousness (but not within the Russian Orthodox Church).

The question naturally arises as to the confessional future of these Jewish atheists and Jews who find it difficult to define their confessional affiliation. Atheism is in general on the decline and Russians are identifying themselves more and more with a 
particular confession. Perhaps most of these 'undefined' Jews are going to become practising Jews in the future. It is not for us to decide which God Russian Jews are to believe in, but an objective analysis shows that the majority of unaffiliated Jews have much the same feelings towards Orthodoxy, as they do towards Judaism. It must also be taken into consideration that practising Jews are more inclined to emigrate than Christian Jews, with the result that the number left in Russia is constantly diminishing and the number of Christian Jews is growing automatically.

Confessional differences, therefore, cannot be either the reason for antisemitism or the basis for a sense of national identity among Russian Jews in Russia today. What other possible basis could there be for mass antisemitism? One essential basis for national intolerance and xenophobia is the existence of a system of criteria by which people are divided into the categories 'us and them', 'ours and theirs'. This system encompasses not only religion, but also language and easily identified national cultural and political values. Are there any fundamental political and cultural values which distinguish Jews from Russians? The answer is: not at present. Politically, Jews rather more than Russians tend to be supporters of democracy, basic citizens' rights and market reforms, but the difference is slight. The majority of city-dwelling Russians also share these political values ${ }^{2}$, and only the 'red-brown' minority — or in fact, only the radical groups within this minority, since many of those who vote for the communists are of a social-democratic persuasion - are hostile to the political values of the Jews.

Do the Jews have any distinguishing cultural characteristics, then? Most Jews and Russians listen to the same music and read the same authors. Jews, in fact, often exhibit a particularly strong interest in classical Russian culture, accepting its values no less fully than do the Russians themselves - they are 'plus royaliste que le roi'. Classical Russian literature is the third most popular genre among Russians after detective and historical novels, but it is the most popular among Jews - almost a quarter of those surveyed put it in first place. Jews number Tolstoy, Chekhov, Lermontov, Bunin, Dostoyevsky and Bulgakov among their favourite authors, and name people such as Likhachev and Solzhenitsyn as their moral and religious authorities, much more often than Russians do. These data show that Jews have not just adapted to the spiritual life of Russia but have a clearly expressed Russian identity.

Jews differ most from Russians in their attitude to Russia's past. This was the conclusion we came to after analysing the answers to the question 'Which period of Russian history do you consider the best?' More than any other group, the Jews look to the modern period of 'perestroika' and Russia today, and amongst historical periods to the Pushkin era, the age of reforms in Russia, and the period of the Provisional Government in 1917 - to periods, that is, most associated with the blossoming of culture and with the victory of 'democracy' rather than with the political regimes associated with 'Russia's greatness'. Generally speaking, and unlike any other nation, it is in the Russia of today that the Jews have 'found themselves' and gained a sense of their historical significance. In this respect they differ greatly from Russians, for whom the best era of Russian history is the reign of Peter I and earlier periods. We see some paradoxical peculiarities in the way Russian Jews view themselves. They largely accept the religion and culture of the Russians around them but they do not identify with Russia's historical past, the greatness of the Russian state or its political and military victories. Thanks to this, they are more consistent democrats, but in their relationship with Russians, there are areas of alientation and incomprehension. Could these be the cause of mass antisemitism? Probably not. These causes are too personal, having little to do with social or political life. 
However, if these differences are not substantial enough in the socio-political sphere, they are, as far as religious life is concerned, on two different levels.

The first level is that of the mass religious consciousness of a broad range of Russian believers. Among both Russians and Jews a transient, amorphous, eclectic consciousness predominates. It is spontaneous (based on Orthodox tradition), Orthodox, Christian and democratic. The current tendency for people to call themselves 'just Christians' together with an orientation towards the values of Russian classical culture provides a comfortable way for Jews to be a part of Russian national culture. Of believers, 5 per cent relate positively towards Jews and 8 per cent relate negatively. This is the same proportion as among the country as a whole. Believers are not, then, the generators of national intolerance.

The second level is that of the small world of church bureaucracy and the "church society' associated with it, formed in the post-war mentality of 'Sergianism'. Opposition to democracy, the ideology of 'patriotic service' to the authoritarian Russian state and the vague ideal of . ioly Rus" which is so significant in these circles stand in direct opposition to the values espoused by Russian Jews. This is not an external conflict, but an internal church confrontation: the question of the Jews and the church is the question of whether the church is going to accept democratic values and norms. The antisemitism of a significant section of the church bureaucracy and of associated circles is quite natural: it is explained by hostility to freedom and democracy, to human rights and to the rest of the Christian world (that is, the West). Racist prejudices, belief in a 'Jewish-Masonic conspiracy' and other antisemitic myths are only a by-product.

\section{Notes and References}

1 This survey was carried out in 15 towns among 2250 people, 69 of whom were Jewish. Articles we have published based on the results include: 'Religioznost' — demokratichnost' - avtoritarnost', Politicheskiye issledovaniya, No. 3. 1993; 'Kak idet religioznoye vozrozhdeniye Rossii', Nauka i religiya, Nos. 5-7, 1993; 'Moral' i religioznost', Disput, No. 4, 1993; 'Intelligentsiya i postsovetsky kapitalism', Svobodnaya mysl', No. 5, 1994; 'La Contestano e pero la amano', Jesus (Milan), No. 6, 1993; 'Freedom of conscience in Russia: what the opinion polls show', Religion State \& Society, vol. 21, nos 3-4, 1993, pp. 375 - 81; 'The prospects for Catholicism in Russia', Religion State \& Society, vol. 22, no. 1, 1994, pp. 69-72; 'The changing pattern of religious belief: perestroika and beyond', Religion State \& Society, vol. 22, no. 1, 1994, pp. 89 - 96; 'Religiosity and political consciousness in post-soviet Russia', Religion State \& Society, vol. 22, no. 4, 1994. pp. 397 402.

2 For an analysis of political attitudes, see L. Vorontsova and S. Filatov, 'Religioznost' demokratichnost' - avtoritamost", Politicheskiye issledovaniya, no. 31993.

(Translated from the Russian by Philip Walters and Emma Watkins) 